Sains Malaysiana 49(2)(2020): 249-259

http://dx.doi.org/10.17576/jsm-2020-4902-03

\title{
Increased Obesity Rate due to Economic Transition and Industrialisation in Asia: A Systematic Review
}

(Peningkatan Kadar Keobesan disebabkan Peralihan Ekonomi dan Pengindustrian di Asia: Suatu Kajian Sistematik)

\author{
Wu-Dong-Yan Goh, Li-ChOo ChOnG*, YAU-Hoong KuAn \& MOHAMEd NoOR Mohamed Ismail
}

\begin{abstract}
Owing to economic transition and urbanisation, nutrition problems in Asia have shifted from malnutrition to overnutrition. As a result, the obesity rate in Asia is rising at an alarming rate. This review aims to provide an overview of the key factors and current strategies of this phenomenon in Asia from the socio-economic point of view as well as to provide insights of possible ways to overcome these issues by analysing works of literature published between 2000 and 2018. Diet-related factors such as energy intake surplus, overconsumption of processed food, fat and sugar are among the largest contributors to this epidemic. The underlying factor of the surplus of energy intake was due to socioeconomic and cultural factors such as improved purchasing power and deep-rooted cultural associations of obesity with prosperity. Efforts have been put in by governments, NGOs, and the food industry to cope with obesity. These include the implementation of dietary guidelines, organisation of public health campaigns, enforcement of nutrition labelling on food products, application of fiscal policy, and marketing ban of energy-dense nutrient-poor (EDNP) food products to children. However, these collective efforts have not been effective. Therefore, authorities should seek long term alternative ways such as food reformulation and 'food zoning' to create a conducive environment that encourages a healthy diet.
\end{abstract}

Keywords: Asia; economic transition; industrialisation; obesity; processed food consumption; socioeconomic factor

ABSTRAK

Keobesan di Asia telah meningkat pada kadar yang membimbangkan disebabkan oleh peralihan ekonomi dan urbanisasi. Kertas ini bertujuan untuk membincangkan punca keobesan daripada segi sosioekonomi dan juga memberi cadangan untuk langkah mengatasi masalah keobesan melalui kajian kepustakaan yang diterbitkan antara tahun 2000 dan 2018. Antara penyumbang terbesar kepada epidemik keobesan ini adalah berkaitan dengan sifat pemakanan seperti pengambilan kalori, makanan diproses, lemak dan gula yang berlebihan. Punca kejadian ini adalah disebabkan faktor sosioekonomi dan budaya seperti peningkatan kemampuan membeli secara umum dan pemikiran yang mengaitkan kekayaan dengan keobesan. Usaha untuk menyelesaikan masalah keobesan yang dijalankan oleh kerajaan, badan bukan kerajaan (NGO) dan industri pemakanan termasuklah menyediakan garis panduan makanan, kempen kesihatan awam, label nutrisi pada produk makanan, dasar kewangan serta larangan promosi makanan yang tidak berkhasiat kepada kanak-kanak. Walau bagaimanapun, usaha tersebut tidak menunjukkan kesan yang menggalakkan. Oleh itu, pihak berwajib seharusnya mencari alternatifjangka panjang lain seperti formulasi semula makanan dan 'pengezonan makanan' untuk mencipta persekitaran kondusif yang menggalakkan diet sihat.

Kata kunci: Asia; faktor sosioekonomi; keobesan; pengambilan makanan diproses; pengindustrian; peralihan ekonomi

\section{INTRODUCTION}

Healthy citizens can contribute to the nation's successful development and economic growth. However, emerging public health issues particularly obesity and overweight, constitute a global economic burden due to loss of productivity (Tremmel et al. 2017). Obesity and overweight issues are affecting more than half a billion people worldwide (Chavasit et al. 2013), not only high-income countries are experiencing the backlash from obesity and overweight, however, developing countries are also facing the same problem.

The World Health Organization (WHO) defines obesity and overweight as the result of excessive fat accumulation that poses health risks (WHO 2016).
Although there are several criteria to classify a person as obese or overweight, it is generally defined by using the body mass index (BMI). An adult over 20 years old who has a BMI of over 30 is considered obese while a BMI between 25 and 30 is considered as overweight (WHO 2016). As of 2018, 39\% of women and 39\% of men aged 18 and above were found to be having BMI over 25 globally (World Health Organization 2016b). While average statistics in Asia is below the world average (World Health Organization 2016b), rates of obesity in Taiwan, Malaysia and Brunei have surpassed the world average at $45.2 \%$ (Huang et al. 2017), 42.5\%, and $41.2 \%$, respectively (World Health Organization 2016b). 
One of the global non-communicable disease (NCD) goals by WHO is to halt the rise of diabetes and obesity worldwide by the year 2025 (Global Nutrition Report 2017). The overweight and obesity rate by 2018 was still on the rise (Global Nutrition Report 2017; Roser \& Ritchie 2018). Besides that, it should be noted that the actual obesity and overweight prevalence in Asia could be higher than reported because Asians have more centralised body fat and it is not optimal to be measured through BMI reading (Mohamed Ismail et al. 2005; Nishida et al. 2004). It was projected by WHO that with the steady rise of obesity rate, it would be close to impossible to achieve the aforementioned goal (Global Nutrition Report 2017).

If the rate of obesity and overweight could not be controlled, a big economic and social strain would be placed on society. Healthcare costs, particularly, would increase greatly. According to a study by Arofiin (The Economist Intelligence Unit 2017), 10-19\% and 8-16\% national healthcare resource were related (directly and indirectly) to obesity in Malaysia and Indonesia, respectively. Besides that, the countries suffering from a high prevalence of obesity would also experience a productive year loss as work forces generally have a shorter lifespan (The Economist Intelligence Unit 2017).

Therefore, this paper aims to discuss the factors that lead to obesity in Asia and at the same time explores the possibilities of alternative ways to overcome this epidemic.

\section{Methods}

\section{ELIGIBILITY CRITERIA}

Countries of interests were loosely classified into four regions based on their geography and socio-cultural background as well as the gross national income (GNI) per capita (The World Bank Group 2018; World Bank Data Team 2019) - East Asia/High income (China, Hong Kong, Japan, South Korea, and Taiwan), Southeast Asia/Upper middle-high income (Brunei, Indonesia, Malaysia, Philippines, Singapore, Thailand, and Vietnam), South Asia/Middle income (Bangladesh, India, Nepal, Pakistan, and Sri Lanka), and Indochina/Middle income (Cambodia, Laos, Myanmar). Key factors, strategies and challenges in coping with obesity in these countries were compared.

\section{INFORMATION SOURCES, SELECTION OF LITERATURE/ SEARCH STRATEGY}

Works of literature including journal articles, book chapters, reports, and periodicals published from 2000 to 2018 on obesity-related topics were searched on the World Health Organization (WHO) official website (WHO 2018), Taylor's Library Portal (Taylor's Education Group 2018) and Google Scholar (Google LLC 2018). Keywords used for search include 'obesity rate in Asia', 'calorie consumption in Asia', 'dietary pattern', 'socioeconomic burden', 'industrialisation' and 'health policy'.

\section{DATA EXTRACTION}

Data on packaged food and beverage consumption and ingredients profile from 2012 to 2018 were extracted on Euromonitor Passport and Mintel GNPD, as Euromonitor Passport provides consumption data of ingredient commodity, which reflects actual usage of ingredients, while Mintel GNPD provides insights on the trends of ingredients usage through new market launch. The trend of change in consumption and ingredients used in processed food and beverage was observed and related to trends reported in the literature searched. The average values of data from the most recent one year were represented in bar charts for comparison across countries.

\section{RESULTS}

In $2018,39 \%$ of women and $39 \%$ of men aged 18 and above were found to have a BMI of over 25 globally (World Health Organization 2016b). Generally, Asian countries have a lower prevalence of overweight and obesity as compared to the global average, except for Taiwan, Malaysia and Brunei (World Health Organization 2016b) (Table 1). The increase in overweight and obesity rate in the Southeast Asia region is alarming, especially when obesity is not culturally recognised as an epidemic (The Economist Intelligence Unit 2017). Although the population with $\mathrm{BMI}>30$ was reported to be the lowest in East Asia, it was found to have a higher overweight population than average, which indicates a potential increase of the obese population in the future.

Under-nutrition was still one of the major problems in Asia until the mid-1950s. However, because of economic transition and urbanisation, nutrition problems in Asia have shifted from under nutrition to over-nutrition, while deficiency diseases remain prevalent in lower-income countries in South Asia and Southeast Asia (Berdanier et al. 2003). As a result, these nations have developed cultural beliefs that do not acknowledge obesity as a chronic epidemic.

\section{OVER CONSUMPTION OF PROCESSED FOOD - SURPLUS} OF SUGAR AND FATS

Overweight and obesity occur when there is an imbalance of energy intake, particularly when the calorie intake is more than energy expenditure. WHO (2015) suggested that the daily intake of total fat should not exceed $30 \%$ (saturated fats less than $10 \%$, trans-fats less than $1 \%$ ); free sugars should be less than $10 \%$ of the total energy

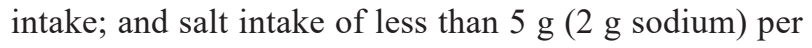
day.

The recommended energy intake differs across regions and demography. In Asia, the recommended daily allowance for energy ranges from 8891 (Thailand) to 12552 $\mathrm{kJ}$ (Indonesia) per day in men and 7333 (Thailand) to 9636 kJ (Singapore) in women (Barba \& Cabrera 2008) (Table 1). The recommended energy intake also differs across age groups and daily physical activities. 
Due to the economic and nutrition transition, food has become more available. Energy consumption has overtaken the recommended daily energy intake over the years. Since 1961, food consumption per capita has increased more than double to almost $13389 \mathrm{~kJ} /$ person/day in East Asia, followed by Southeast Asia (over 50\%) and finally South Asia (30\%) (FAO 2018). It is also noted by Alexandratos and Bruinsma (2012) that food consumption increases with the income level of the countries. As a country becomes more developed, the standard of living rises, hence increasing food availability (Alexandratos \& Bruinsma 2012).
Although Singapore had a higher recommended daily energy allowance than most Asian countries, it was reported that in $2010,59.4 \%$ of Singaporeans had energy intake higher than the recommended level (Foo et al. 2013). This is in line with the report by FAO (2018) whereby energy consumption per capita is directly proportional to the country's income. Surprisingly, even with the high prevalence of overweight and obesity rates, it was found that the median energy uptake of Malaysians was only $64 \%$ of the recommended level.

In 2017 , the average energy consumption of the Indonesian population exceeded $2.5 \%$ of the recommended

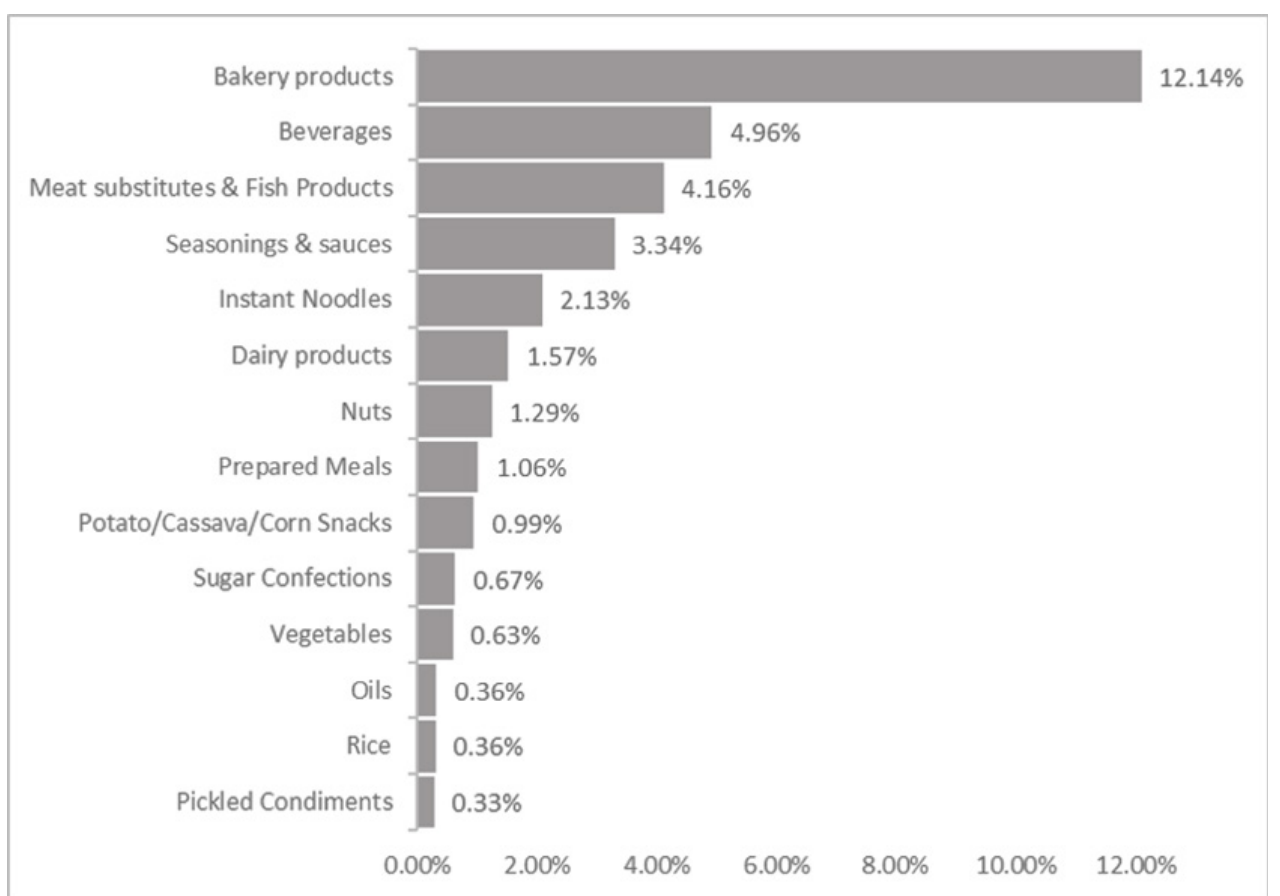

FIGURE 1. Top launched product categories across Asian region from 2013-2018 (Mintel Group Ltd. 2018b)

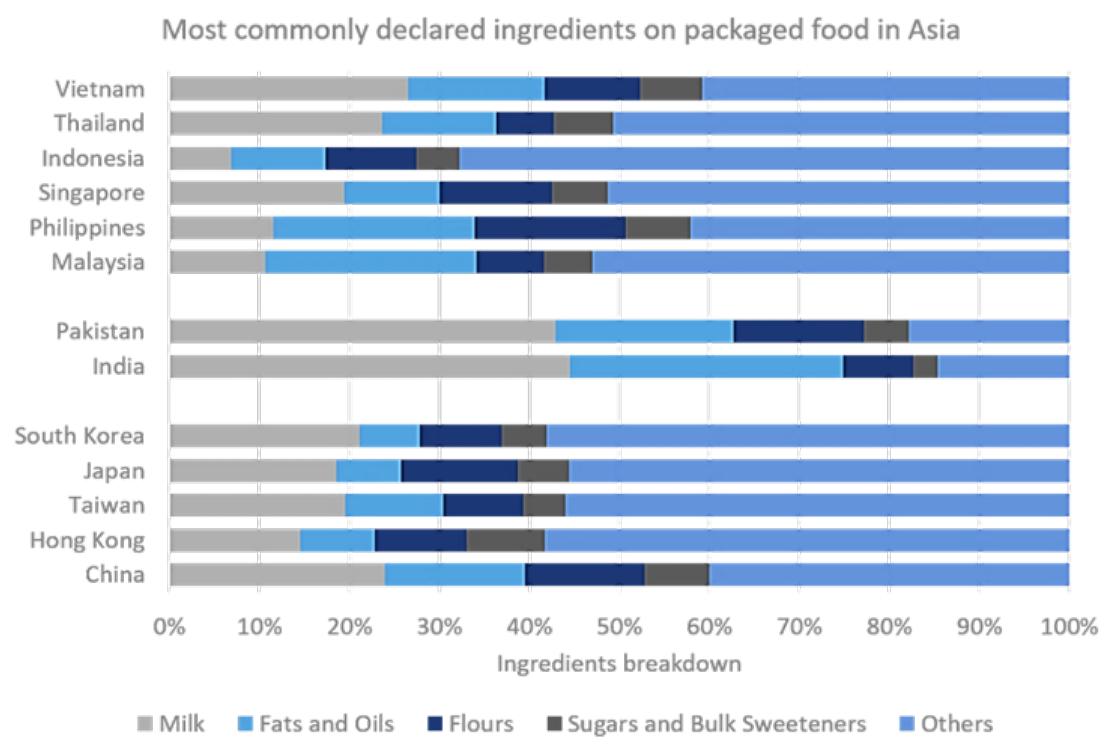

FIGURE 2. Top ingredients appearing on food labelling of packaged foods from 2013-2018 (Mintel Group Ltd 2018b) 


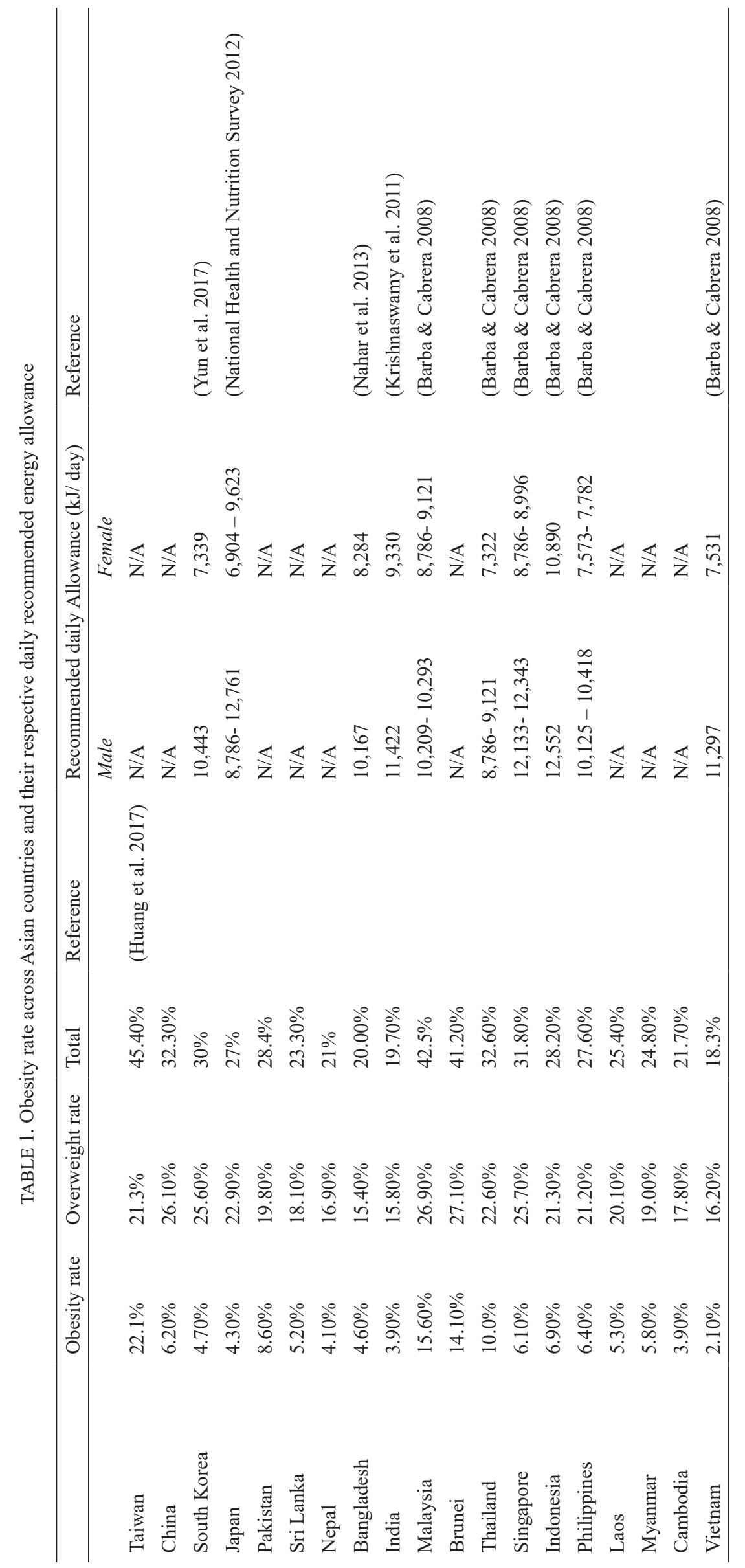


intake by the National Food and Nutrition Forum (WNPG). Similarly, Arifin et al. (2018) reported that the surplus of energy consumption was contributed by the population living in the two highest income quintiles, where they exceeded the recommended daily allowance by $123.8 \%$ and $112.3 \%$, respectively.

Globally, a daily energy content of $3200 \mathrm{~kJ}$ per capita was purchased on packaged food and soft drinks, which is almost $40 \%$ of the WHO daily recommended energy intake allowance. Among them, $837 \mathrm{~kJ}$ is contributed by bakery products. In terms of ingredients, fats and oils are the top contributors, followed by dairy, soft drinks and confectioneries. A similar trend was observed in Asia region (Figure 1), whereby bakery products are among the highest launched products $(12.14 \%)$, coming down to beverages (4.96\%), then savoury products (meat, seasoning $\&$ instant noodles) $(9.63 \%)$ and lastly dairy products (1.57\%) (Mintel Group Ltd 2018b). The main ingredients of these products are flour, sugar, and fats. The energy content of these products is at least $1464 \mathrm{~kJ} / 100 \mathrm{~g}(\mathrm{~mL})$, which makes these products energy-dense food. Since these energy-dense packaged foods are consumed in addition to the main meals (Baker \& Friel 2014), they contributed to excessive intake of energy which would eventually become the reason for obesity.

Increased consumption of westernised food and processed food among Asians was believed to be one of the major contributors to the rising obesity rates (IPH 2014). According to Arofiin (The Economist Intelligence Unit $2017), 22 \%$ of the obese population (17\% more than nonobese population) in Malaysia, Singapore, Indonesia, Thailand, Vietnam and the Philippines claimed that they eat 'westernised' food over three times a week. They are also $9 \%$ more likely to consume processed food three times a week than non-obese respondents. Studies conducted in Taiwan (Huang et al. 2017), China (Cheng et al. 2017), and Japan (Murakami et al. 2017) also found associations between westernised and processed foods with obesity. However, another cross-sectional study conducted by Lipoeto et al. (2013) in the Southeast Asia region (Malaysia, Philippines, and Indonesia) found that 'the Western food franchises and culture have not yet overwhelmed the local food culture in this region'. The nutrition transition may be due to the increase in the availability of food and therefore, food purchasing power as well (Lipoeto et al. 2013). Similar findings were reported by Raghav et al. (2014) in a study conducted in Jharna of Jaipur District of Rajasthan, India, whereby $73 \%$ of the local population was not aware of fast food. Nonetheless, both studies by Lipoeto et al. (20130 and Raghav et al. (2014) did not deny the association between consumption of processed food and soft drinks with the increased risk of obesity as obese and overweight population derived most of their calories from beverage and confectioneries (Fokeena et al. 2015).

The increase in consumption of westernised and processed food also leads to a surplus of fats and sugar consumption. For instance, it is found that the prevalence of obesity in Malaysia was due to the usage of low-quality cooking oils during deep-frying, a common technique used in Western cooking (Micha et al. 2014) and high sugar consumption from packaged soft drinks (Lim 2016).

\section{FAT CONSUMPTION}

Fat consumption behaviour differs across countries due to sociocultural and geographical factors. In 2010, the mean global saturated fat intake in adults was $9.4 \%$ of the recommended energy intake of WHO. In Asia, Malaysia was identified as one of the nations with the highest saturated fats consumption (20.3\% of energy intake; world average $=9.4 \%$ of energy intake) whereas South and East Asia were reported to have the lowest consumption (Micha et al. 2014). Due to the abundance of saturated fats sources such as palm oil, countries in Southeast Asia were also noted to have the lowest consumption of polyunsaturated fats from 'healthful vegetable oil' (Micha et al. 2014).

From the ingredients profile of packaged foods (Euromonitor International 2018), ingredients that are most commonly used are dairy, followed by fats and oils in India and Pakistan. This is due to the highest launches of dairy products and oils/fat spread, such as Asli ghee and Vanaspati ghee. Although these ingredients are highly consumed, they are mostly used as cooking oil, which is found to reduce serum lipid levels (Mohammadifard et al. 2010), hence the lower prevalence of overweight in this region. Dairy ingredients were used the most in Singapore and South Korea, followed by flour, then fats and oils, finally sugars and bulk sweeteners. Malaysia, Indonesia, and the Philippines had the lowest usage of dairy ingredients and the highest oils and fats usage (Euromonitor International 2018). This suggests that the food product in these countries are high in calories.

\section{SUGAR CONSUMPTION}

Energy intake derived from caloric sweeteners in Asian diets has increased dramatically in the past decade. It was reported by Baker and Friel (2014) that the annual sugar consumption per capita in upper-middle-income Asian countries (GNI per capita USD 4,086-12,615) increased from $12 \mathrm{~kg}$ to $31 \mathrm{~kg}$. Besides that, the highest income groups (GNI per capita $>$ USD 12,616) increased the most at $800 \%$, while consumption in the lower-middle-income countries (GNI per capita USD 1,036-4,085) also experienced a growth of $200 \%$ from $3 \mathrm{~kg}$ to $9 \mathrm{~kg}$.

According to a report by Euromonitor (Bandy 2015), in 2014, the highest consumption of sugar in processed food is derived from soft drinks (11.5 g per capita per day), despite having the lowest sugar content per $100 \mathrm{~g} / \mathrm{mL}$ (5 $\mathrm{g} / 100 \mathrm{~mL}$ ). This is followed by dairy products, which include milk, yoghurt and condensed milk, sugar confectioneries and baked goods, respectively.

In addition, it was found that in 2016, the amount of sugar consumed in Southeast Asia per capita per day was the highest in Thailand at slightly over $15 \mathrm{~g}$ per capita per day, followed by the Philippines, Malaysia, and Singapore 


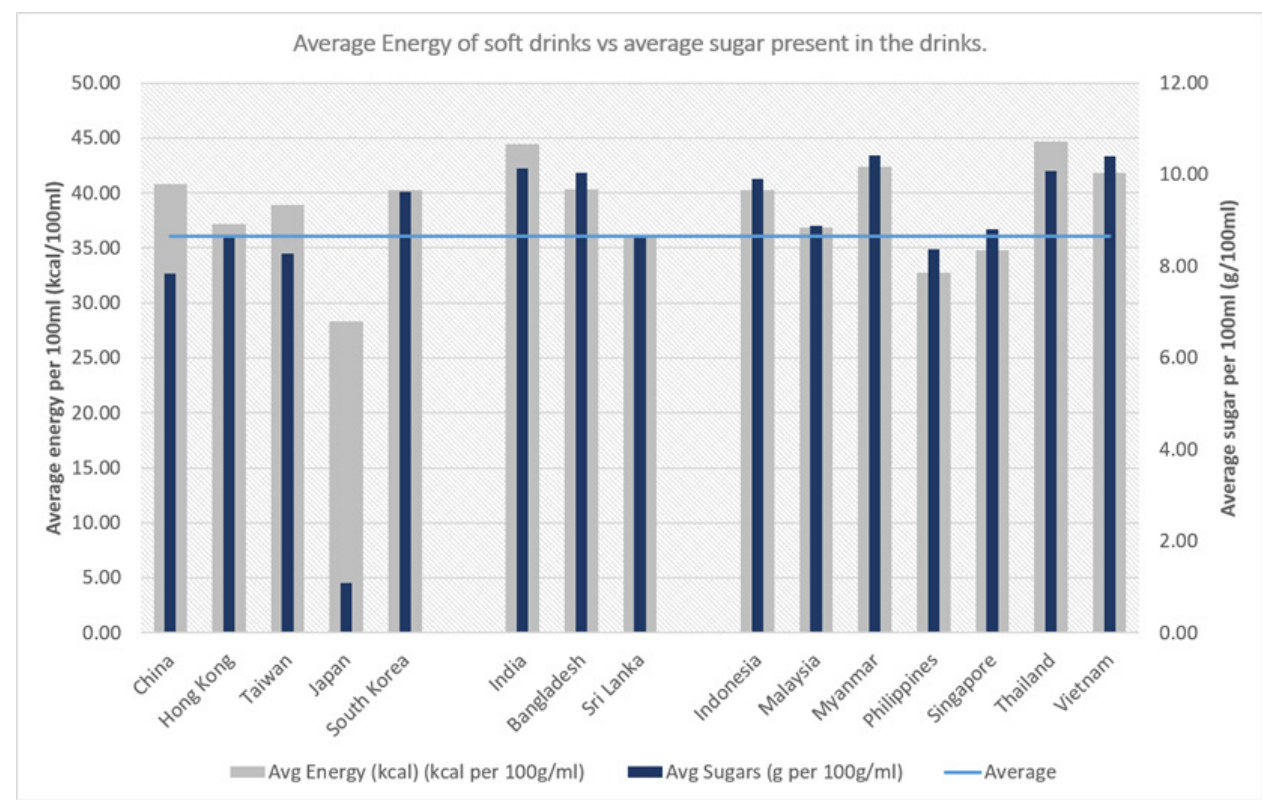

FIGURE 3. Average sugar content vs average energy content in soft drinks (Mintel Group Ltd 2018a)

(Lim 2018). Indonesia and Vietnam have surprisingly low consumption of sugar from soft drinks compared to other countries. This was explained by the preference of bottled water over soft drinks at home in Indonesia and RTD tea which contains a low sugar level in Vietnam. In the same report, the author illustrated that sugar consumption was the main reason for obesity in Thailand and the Philippines, while the higher obesity rate in Malaysia and Singapore was due to factors beyond sugar consumption in soft drinks. However, another study by Boo et al. (2010) found that the consumption of soft drinks was a significant risk factor associated with being overweight among medical students in a Malaysian public university. Malaysia's high sugar consumption was partly due to the government's subsidy on sugar price (The Economist Intelligence Unit 2017). However, Rampal et al. (2007) argued that 'the increasing rate of sugar consumption in Malaysia should be viewed as sugar addiction' (Amarra et al. 2016).

Wang et al. (2018) estimated that the mean total sugar intake of South Koreans was $61.4 \mathrm{~g} /$ person/day, which accounted for $12.8 \%$ of total daily energy intake. $35 \mathrm{~g}$ of the sugar intake was derived from processed foods, of which granulated sugar took up the highest proportion, followed by carbonated drinks, coffee, bread, and fruit juices (Turner 2014). Consumption of sugar-sweetened beverages increased the most in adolescents, while tea and coffee consumption doubled in adults and tripled in the middle-aged group (Lee et al. 2012).

Among the countries, Japan has the most concern over sugar consumption, as the sugar content in soft drinks found in Japan was extremely low compared to other nations (Mintel Group Ltd. 2018a) despite beverages being reported as the main contributor of sugar intake among Japanese children (Takeichi et al. 2012).

\section{SOCIOECONOMIC BURDEN}

Thailand, Indonesia, Philippines, and Vietnam, as well as the South Asian countries, are experiencing double burden with rising trends in both prevalence of obesity and undernutrition. This was thought to be linked to the recent recovery from poverty where the public has yet to recognise the threat of obesity, leading to the overfeeding of children due to families focusing their resources on a smaller number of children (The Economist Intelligence Unit 2017).

As a result, the perception of excess weight as a sign of prosperity and wealth makes it even harder to encourage people to adopt a healthy diet (Lipoeto et al. 2013). The advertising of unhealthy food products to children was also rampant in countries like India, Malaysia and the Philippines (Consumers International Asia Pacific Office 2002). Social media drowned with food posts was also a contributing factor to the obesogenic environment (Mognard et al. 2016).

In Indonesia, the rate of children suffering from overweight and obesity is the same rate as the children who suffer from moderate nutrition, which is at $12 \%$. In Thailand, both overweight and wasting in children also increased from $8 \%$ to $11 \%$ and $5 \%$ to $7 \%$, respectively, between 2006 and 2012 (The Economist Intelligence Unit 2017). This phenomenon is also observed in India whereby the prevalence of over-nutrition is emerging as a significant problem in the urban areas due to economic transition, while under-nutrition remained a major problem too (International Institute for Population Sciences (IIPS) \& Macro International 2017).

Besides, cultural factors also complicate the fight against obesity. Asians generally love eating. The abundance of cheap, unregulated street food and convenience stores makes food available all day long (The Economist Intelligence Unit 2017). Also, 
'supermarketisation' made food (dominantly processed foods) more accessible to the public. Baker and Friel (2014) observed that market segmentation was the reason for sugar and fat consumption from processed foods at the later stages of economic development. However, Lipoeto et al. (2013), stated that the shift in diet habits and diet structures can only be partially explained by economic factors, whereby the improvement of economic factors increased the people's food purchasing power but did not account for the change in food preferences.

\section{CURRENT STRATEGY}

The government and the food industry have been working hand in hand to curb overweight and obesity. Measures taken are classified into two main modes of actions: restrictive activities such as limiting availability and marketing of unhealthy food and beverage to promote a less obesogenic environment; and proactive activities through informational and educational actions (WHO 2018). Generally, the implementation of educational and informational actions was higher than structural actions to improve the food environment. Educational actions include providing dietary guidelines, regulating nutrition labelling, regulation of nutrition and health claims, regulation of marketing of food and non-alcoholic beverage to children, media campaigns and giving nutrition and diet counselling, whilst structural actions to improve food environment include reformulation of food and beverage products, banning of trans-fat, implementation of fiscal policies, and portion size control (WHO 2018).

Based on the study done by Policy and Scientific Advice Unit (NPU) of WHO (2018), 100\% of member countries in the SEARO (11 of 11 Member States in the South-East Asia Region (Bangladesh, Bhutan, Democratic People's Republic of Korea, India, Indonesia, Maldives, Myanmar, Nepal, Sri Lanka, Thailand, Timor-Leste) and WPRO (25 of 27 Member States in the Western Pacific Region (Australia, Brunei Darussalam, Cambodia, China, Cook Islands, Fiji, Japan, Lao PDR, Malaysia, Marshall Islands, Micronesia (Federated States of), Mongolia, New Zealand, Niue, Palau, Papua New Guinea, Philippines, Republic of Korea, Samoa, Singapore, Solomon Islands, Tonga, Tuvalu, Vanuatu, Vietnam) regions participating in the survey executed at least one educational measure, while only $27 \%$ of the participating countries in those regions employed the improvement of food environment approach. The implementation of dietary guidelines, regulation for nutrition labelling and nutrition and health claims, organisation of media campaigns on healthy diets, and counselling on nutrition and healthy diets through public health campaigns were the most popular actions taken by most of the countries. While the SEARO region only focused on the basic educational measures, WPRO countries focused on the implementation of fiscal policies, regulation of marketing activities of food and non-alcoholic products to children and controlling food portion size to prevent overweight and obesity.

\section{DISCUSSION}

\section{OVERCONSUMPTION OF ENERGY DUE TO INDUSTRIALISATION}

Asian countries, especially South and Southeast Asia, are currently undergoing rapid economic transition resulting in the substantial growth of the food manufacturing industry. A study conducted in Jakarta, Indonesia found that non-processed food and processed ingredients contributed to most energy and nutrient intakes. However, at the same weight consumption, processed ingredients provided higher intakes of energy, fat, sodium, and sucrose than other food groups (Setyowati et al. 2018).

It was reported that the consumption of processed, packaged and convenience food in high-income countries such as Japan has reached a plateau since the 1990s. Currently, the consumption rate in upper-middle- (China and Thailand) and lower-middle-income countries (Malaysia, Indonesia, and the Philippines) are catching up substantially to that of the higher-income countries (Baker \& Friel 2014). Carbonated soft drinks, baked goods, and oils and fats are the major processed foods launched and consumed in these countries (Mintel Group Ltd 2018a). These products are averagely more than 1464 $\mathrm{kJ}$ per $100 \mathrm{~g} / \mathrm{mL}$ and are hyper-palatable due to their high levels of sugar, salt, and fat (Kelly 2016). It is noteworthy that the types of products consumed across the region were slightly different. Thailand and the Philippines had the highest soft drink consumption while Malaysia and Indonesia had the most consumption of high-fat foods. It was also observed that there is a dramatic shift of dietary energy intake from complex carbohydrates to oils and fats over this past decade (Kelly 2016), which explained the increase rate of obesity, especially in the higher income groups.

Huang et al. (2017) suggested obesity to be tackled differently due to the different dietary patterns among residents in cities, townships and rural areas. With urbanisation, energy-rich diets containing higher amounts of fat and sugar and lower dietary fibre and complex carbohydrates are being consumed frequently, particularly by high-income groups (Krishnaswamy et al. 2011). This shift of diet from traditional staple food such as cereal and starchy roots to non-staple food such as livestock products, oil crops, sugar, fruits, and vegetables is observed in the late 1980 s to early 1990 s (FAO 2018). This, in turn, increased the energy intake from protein and fats and reduced the energy intake from carbohydrates. The shift was the clearest in East Asia, followed by Southeast Asia, and the least in South Asia. It was also noted that although the protein intake in South Asia and Southeast Asia are approximately the same, the vegetable-source protein consumed in South Asia was not of the same nutritional quality as the animal-sourced protein consumed in Southeast Asia (FAO 2018). 
URBANISATION, SOCIO-ECONOMIC STATUS AND CULTURAL IMPACT ON THE RISING OBESITY RATE

In Asia, food carries not only the function of nourishment, but it is also an important tool to establish and express relationships. Asians generally love eating and many social activities revolve around food. For example, 'huisik' culture in Korea is practised to improve work dynamics in the company, and dumpling eating during the Spring Festival in China to maintain the relationship between people and God (Ma 2015). Often, these activities involve not only a single meal but is likely to be extended into several rounds of meals per session or even days of celebration during festivities. This would lead to overeating during these periods of time and eventually planted the seed for obesity.

Instead of proper dining in restaurants, the street food culture has greatly impacted eating behaviour among Asians (The Economist Intelligence Unit 2017). The abundance of cheap, unregulated street food, which is often high in fats and sugar, and the availability of instant food in convenience stores make food available all day long. This has resulted in snacking behaviour outside of regular mealtimes, especially late at night, which in turn, increases energy consumption.

The perception of excess weight as a sign of prosperity and wealth makes it even harder to encourage people to adopt a healthy diet (Lipoeto et al. 2013). It is especially obvious when a minimal effort was given by the government to combat this issue. In 2011, 'there has been little activity in Vietnam in addressing the increasing prevalence of overweight and obesity in children and adults and no budget had been allocated to the task' (Development Initiative 2017). Although more effort was being made over the years, it is harder to break these inherent cultural beliefs.

On the other hand, it was observed by Lipoeto et al. (2013) that despite the abundance of the fast-food chain in metropolises like Kuala Lumpur and Manila, the people still maintained their own food consumption patterns. Western food was considered a snack food for leisure and recreation. They discussed that the nutrition transition in Southeast Asia was contributed by the tremendous socioeconomic development. Food has become more affordable. Hence, food expenditure and consumption increased dramatically. In addition, the shift of labour-intensive occupations to service- and manufacturing-related jobs has greatly reduced the energy expenditure at work. This is in line with the findings by Arifin et al. (2018), whereby surplus of energy consumption was contributed by the population living in the two highest income quintiles, where they exceeded the recommended daily allowance by $123.8 \%$ and $112.3 \%$, respectively. The two lowest income quintiles had a daily consumption of less than $80 \%$ of the recommended value, which is considered nutrient deficient. A similar phenomenon was also reported by Tanzil and Jamal (2016) where the lower-income groups suffer from under-nutrition and high-income groups suffer from over-nutrition.
On top of that, 'supermarketisation' also made food (dominantly processed foods) more accessible to the public. Baker and Friel (2014) observed that market segmentation was the reason for sugar and fat consumption from processed foods at the later stages of economic development. Refined carbohydrates, ingredients with higher sugar and oil content, as well as animal products were introduced into traditional cooking as the main ingredients (Drewnowski \& Popkin 2009).

Next, the birth of 'foodie culture' on social media. Social media drowned with food posts, which in turn encourages urbanites to constantly be in search of food. This has indirectly contributed to the obesogenic environment (Mognard et al. 2016).

\section{THE WAY FORWARD}

It was highlighted mix strategies should be practised to amplify the effort of curbing the obesity rate. Organising mass media campaign was effective in instilling knowledge related to healthy behaviour, and when coupled with regulations and education-based approaches, it was believed that effect would be amplified (Randolph et al. 2012). However, despite these collective efforts, the rate of obesity in Asia is still rising rapidly, especially in developing countries. Financial instability was one of the reasons for the increase in obesity prevalence, as rural households are unable to afford nutritious foods. Also, the lack of evaluation of the effectiveness of government policy which has been implemented also aided in this scenario (Global Nutrition Report 2017; World Health Organization (WHO) 2016).

Another reason which led to the increase in the obesity population was the presence of a rampant obesogenic environment. Lakerveld et al. (2012) predicted that the sales of the low-fat and low-sugar product will decline due to the shifting trend from buying packaged food to preparing own meals. This is because 'products that are marketed as 'reduced' are thought of by some consumers as being poorer in flavour and taste compared to their 'fullfat' variants' (Bandy 2015). This was also confirmed by a study done in Singapore (Sim \& Cheon 2019) whereby products with 'reduced' labels encourage restrained eating behaviour more than products that emphasise on the health benefits.

Reformulation of food products is usually a voluntary commitment of individual companies, although it could not be denied that local regulations and fiscal policies have encouraged this practice. The most common measure taken was salt reduction in bakery products. Reduced sugar and trans-fat-free products are results of fiscal policies and trans-fat ban. In addition to that, some larger food companies took a step further by incorporating fibre and aeration into food products to reduce the energy density of the food products (WHO 2018).

However, reformulation was among the least adopted measures by countries in Asia due to limited funds for research development. Many of the food products are also 
imported, making it harder to communicate with manufacturers abroad. In addition, reduced fat, sugar and salt products are often inferior in palatability (Kelly 2016), resulting in lower customer acceptance.

Therefore, it is a long-term effort that requires cooperation between food retailers and the government in order to stimulate reformulation and consumer demand for healthier food choices. Factors beyond ingredients reduction and substitution should also be considered. Portion size control is one of the methods least explored, but in fact, the research of sensory-specific satiety and sensory-specific desire holds the potential of designing food products intelligently. For example, a more viscous beverage elicits higher perceived satiety than a less viscous beverage (Mars et al. 2009). Creamier products achieved by emulsification are also perceived as being more 'filling' than a non-emulsified product (Corstens et al. 2018). By modifying food texture, satiety and satiation could be achieved earlier without affecting its palatability, hence reducing portion intake.

The Economist Intelligence Unit (The Economist Intelligence Unit 2017) also reported that interventions on target food intake showed the most impact at reducing the obesity rate. Therefore, food 'zoning' should also be practised whereby the availability of unhealthy food is restricted. It has been proven that creating a conducive environment that encourages the adoption of a healthy diet is more effective to promote healthy eating than trying to change one's eating behaviour.

\section{CONCLUSION}

The rate of obesity in Asia is rocketing due to reliance on sugar- and fat-rich processed foods, as well as the reduced consumption of freshly prepared food. Although awareness for healthy eating has increased over the decades, conventional methods of curbing obesity were found to be lacking. Therefore, alternative methods involving information, food science and technology must be explored in order to achieve the WHO's NCD global target of halting the rise of global obesity.

\section{ACKNOWLEDGEMENTS}

We would like to extend our gratitude to Taylor's Flagship Research Fund, TUFR/2017/003/02, for supporting this study.

\section{REFERENCES}

Alexandratos, N. \& Bruinsma, J. 2012. World Agriculture towards 2030/2050: The 2012 Revision. ESA Working Paper No. 12-03. Rome: Agricultural Development Economics Division, Food and Agriculture Organization of the United Nations (FAO).

Amarra, M.S.V., Khor, G.L. \& Chan, P. 2016. Intake of added sugar in Malaysia: A review. Asia Pacific Journal of Clinical Nutrition 25(2): 227-240. https://doi.org/10.6133/ apjen.2016.25.2.13
Arifin, B., Achsani, N.A., Martianto, D., Sari, L.K. \& Firdaus, A.H. 2018. Modeling the Future of Indonesian Food Consumption. Final Report FAO. pp. 1-69. https://docs.wfp. org/api/documents/WFP-0000073760/download/.

Baker, P. \& Friel, S. 2014. Processed foods and the nutrition transition: Evidence from Asia. Obesity Reviews 15(7): 564577. https://doi.org/10.1111/obr.12174.

Bandy, L. 2015. Where Are Our Calories Coming from? Actions Being Taken to Improve Nutrition. https://www.euromonitor. $\mathrm{com} /$ where-are-our-calories-coming-from-actions-beingtaken-to-improve-nutrition/report

Barba, C.V.C. \& Cabrera, M.I.Z. 2008. Recommended dietary allowances harmonization in Southeast Asia. Asia Pacific Journal of Clinical Nutrition 17(2): 405-408.

Berdanier, C.D., Dwyer, J.T. \& Heber, D. 2003. Handbook of Nutrition and Food. 3rd ed. Boca Raton: CRC Press.

Boo, N.Y., Chia, G.J.Q., Wong, L.C., Chew, R.M., Chong, W. \& Loo, R.C.N. 2010. The prevalence of obesity among clinical students in a Malaysian medical school. Singapore Medical Journal 51(2): 126-132.

Chavasit, V., Kasemsup, V. \& Tontisirin, K. 2013. Thailand conquered under-nutrition very successfully but has not slowed obesity. Obesity Reviews 14(S2): 96-105. https:// doi.org/10.1111/obr.12091.

Cheng, M., Wang, H., Wang, Z., Du, W., Ouyang, Y. \& Zhang, B. 2017. Relationship between dietary factors and the number of altered metabolic syndrome components in Chinese adults: A cross-sectional study using data from the China Health and Nutrition Survey. BMJ Open 7(5): 1-12. https://doi.org/10.1136/bmjopen-2016-014911.

Consumers International Asia Pacific Office. 2002. The Junk Food Generation: A Multi-Country Survey of the Influence of Television Advertisements on Children.

Corstens, M.N., Berton-Carabin, C.C., Schroën, K., Viau, M. \& Meynier, A. 2018. Emulsion encapsulation in calciumalginate beads delays lipolysis during dynamic in vitro digestion. Journal of Functional Foods 46(5): 394-402. https://doi.org/10.1016/j.jff.2018.05.011.

Development Initiative. 2017. Global Nutrition Report. Vietnam: Nutrition Country Profile. pp. 1-2. www. globalnutritionreport.org.

Development Initiatives. 2017. Global Nutrition Report: Nourishing the SDGs. Bristol, UK: Development Initiative. p. 115. https://doi.org/10.1891/1058-1243.21.1.9

Drewnowski, A. \& Popkin, B.M. 2009. The nutrition transition: New trends in the global diet. Nutrition Reviews https://doi. org/10.1111/j.1753-4887.1997.tb01593.x.

Euromonitor International. 2018. Packaged Food in Asia by Ingredients. http://www.portal.euromonitor.com.ezproxy. taylors.edu.my/portal/statisticsevolution/index.

Fokeena, W.B., Jamaluddin, R. \& Khaza'ai, H. 2015. Contribution of different food groups to the energy intake and weight status of adults: A cross-sectional study in a Malaysian public university. Asian Journal of Clinical Nutrition 7(2): 45-54. https://doi.org/10.3923/ ajcn.2015.45.54.

FAO, F. 2018. State of Food and Agriculture in Asia and the Pacific Region, including Future Prospects and Emerging Issues. FAO Regional Conference for Asia and the Pacific. p. 34.

Foo, L.L., Vijaya, K., Sloan, R.A. \& Ling, A. 2013. Obesity prevention and management: Singapore's experience. Obesity Reviews 14(S2): 106-113. https://doi.org/10.1111/ obr.12092. 
Huang, K.C., Yang, H.C., Pan, W.H., Chang, H.C., Yeh, C.J., Chen, H.H. \& Chang, H.Y. 2017. Morbid obesity in Taiwan: Prevalence, trends, associated social demographics, and lifestyle factors. Plos ONE 12(2): e0169577. https://doi. org/10.1371/journal.pone.0169577.

International Institute for Population Sciences (IIPS), \& Macro International. 2017. National Family Health Survey (NFHS4) 2015-16 India. https://doi.org/kwm120 [pii]10.1093/aje/ kwm120.

IPH. 2014. National Health and Morbidity Survey 2014: Malaysian Adult Nutrition Survey (MANS): Vol. III Food Consumption Statistics of Malaysia. Institute for Public Health, Ministry of Health, Malaysia. https://doi. org/10.1007/s13398-014-0173-7.2.

Kelly, M. 2016. The nutrition transition in developing Asia: Dietary change, drivers and health impacts. In Eating, Drinking: Surviving - The International Year of Global Understanding - IYGU, edited by Jackson, P., Spiess, W.E.L. \& Sultana, F. Switzerland: Springer, Cham. pp. 83-90.

Krishnaswamy, K., Bhat, R.V., Ghafoorunissa, Raghuram, T.C., Raghuramulu, R. \& Vijayaraghavan, K. 2011. Dietary guidelines for Indians-A manual. National Institute of Nutrition 3(1): 89-116.

Lakerveld, J., Brug, J., Bot, S., Teixeira, P.J., Rutter, H., Woodward, E., Samdal, O., Stockley, L., De Bourdeaudhuij, I., van Assema, P., Robertson, A., Lobstein, T., Oppert, J-M., Ádány, R. \& Nijpels, G. 2012. Sustainable prevention of obesity through integrated strategies: The SPOTLIGHT project's conceptual framework and design. BMC Public Health 12: 793. https://doi.org/https://dx.doi. org/10.1186/1471-2458-12-793.

Lee, H.S., Duffey, K.J. \& Popkin, B.M. 2012. South Korea's entry to the global food economy: Shifts in consumption of food between 1998 and 2009. Asia Pacific Journal of Clinical Nutrition 21(4): 618-629.

Lim, K.G. 2016. A review of adult obesity research in Malaysia. Medical Journal of Malaysia 71(Suppl. 1): 1-19.

Lim, N. 2018. War on Sugar Consumption in Soft Drinks Southeast Asia. https://www.euromonitor.com/ developments-in-the-war-on-sugar-in-soft-drinkssoutheast-asia/report.

Lipoeto, N.I., Khor, G.L. \& Angeles-Agdeppa, I. 2013. Food consumption patterns and nutrition transition in South-East Asia. Public Health Nutrition 16(9): 1637-1643. https://doi. org/10.1017/S1368980012004569.

Ma, G.S. 2015. Food, eating behavior, and culture in Chinese society. Journal of Ethnic Foods 2(4): 195-199. https://doi. org/10.1016/j.jef.2015.11.004.

Mars, M., Hogenkamp, P.S., Gosses, A.M., Stafleu, A. \& De Graaf, C. 2009. Effect of viscosity on learned satiation. Physiology and Behavior https://doi.org/10.1016/j. physbeh.2009.04.018

Micha, R., Khatibzadeh, S., Shi, P.L., Fahimi, S., Lim, S., Andrews, K.G., Engell, R.E., Powles, J., Ezzati, M. \& Mozaffarian, D. (on behalf of the Global Burden of Diseases Nutrition and Chronic Diseases Expert Group (NutriCoDE). 2014. Global, regional, and national consumption levels of dietary fats and oils in 1990 and 2010: A systematic analysis including 266 country-specific nutrition surveys. BMJ 348: g2272. https://doi.org/10.1136/bmj.g2272.

Mintel Group Ltd. 2018a. Average Energy per $100 \mathrm{~g} / \mathrm{ml}$ of Product Launches in Asia Pacific Region from 2013 2018. https://www.gnpd.com/sinatra/analysis/tabulate/
rT67kiAgxs/?analysis_id=e 122587e-6e5d-4500-9b18$36 \mathrm{ed} 7 \mathrm{f} 17 \mathrm{e} 403$.

Mintel Group Ltd. 2018b. Top Launched Product Categories Across Asian Region from 2013-2018. Mintel GNPD website: https:/www.gnpd.com/sinatra/analysis/chart results/search/FdfK9jKoo9/?analysis id=aac5661f-bee645a1-aa25-d86232be082c\&current tab=aac5661f-bee645a1-aa25-d86232be082c.

Mohamed Ismail Noor, Poh Bee Koon \& Zawiah Hashim. 2005. Strategy for the Prevention of Obesity - Malaysia. Kuala Lumpur: Technical Committee on Strategies for the Prevention of Obesity Malaysia, Malaysian Association for the Study of Obesity (MASO).

Mognard, E., Poulain, J.P., Ismail, M.N., Laporte, C., Fournier, T., Tibère, L. \& Sharif, S.P. 2016. Eating patterns and prevalence of obesity. Lessons learned from the Malaysian Food Barometer. Appetite 107: 362-371. https://doi. org/10.1016/j.appet.2016.08.009.

Mohammadifard, N., Nazem, M., Naderi, G.A., Saghafian, F., Sajjadi, F., Maghroon, M. \& Nouri, F. 2010. Effect of hydrogenated, liquid and ghee oils on serum lipids profile. ARYA Atherosclerosis 6(1): 16-22.

Murakami, K., Livingstone, M.B.E., Okubo, H. \& Sasaki, S. 2017. Energy density of the diets of Japanese adults in relation to food and nutrient intake and general and abdominal obesity: A cross-sectional analysis from the 2012 National Health and Nutrition Survey, Japan. British Journal of Nutrition 117(1): 161-169.

Nahar, Q., Faruque, M.O., Sultana, S.S.S. \& Siddiquee, M.A. 2013. Desirable Dietary Pattern for Bangladesh. Bangladesh Institute of Research and Rehabilitation in Diabetes, Endocrine and Metabolic Disorders (BIRDEM). pp. 1-144. http://fpmu.gov.bd/agridrupal/sites/default/files/ ToR 15- Fial Report BIRDEM.pdf.

National Health and Nutrition Survey. 2012. http://www. nibiohn.go.jp/eiken/english/research/pdf/nhns2012.pdf.

Nishida, C., Barba, C., Cavalli-Sforza, T., Cutter, J., Deurenberg, P., Darnton-Hill, I. \& Zimmet, P. 2004. Appropriate bodymass index for Asian populations and its implications for policy and intervention strategies. The Lancet 363(9403): 157-163.

Raghav, P.K., Agarwal, N. \& Singh, R. 2014. Assessment of food habits \& nutritional status of Jharna adults, Jaipur, Rajasthan. International Journal of Engineering Sciences \& Research Technology 3(7): 106-115.

Rampal, L., Rampal, S., Geok, L.K., Md Zain, A., Ooyub, S., Rahmat, R., Noor Ghani, S. \& Krishnan, J. 2007. A national study on the prevalence of obesity among 16,127 Malaysians. Asia Pacific Journal of Clinical Nutrition 16(3): 561-566.

Randolph, K.A., Whitaker, P. \& Arellano, A. 2012. The unique effects of environmental strategies in health promotion campaigns: A review. Evaluation and Program Planning 35(3): 344-353.

Roser, M. \& Hannah, R. 2018. Burden of Disease. Our World in Data. https://ourworldindata.org/burden-of-disease.

Setyowati, D., Andarwulan, N. \& Giriwono, P.E. 2018. Processed and ultraprocessed food consumption pattern in the Jakarta individual food consumption survey 2014. Asia Pacific Journal of Clinical Nutrition 27(4): 840-847.

Sim, A.Y. \& Cheon, B.K. 2019. Influence of impending healthy food consumption on snacking: Nudging vs. compensatory behaviour. Physiology and Behavior 198(2018): 48-56 
Takeichi, H., Taniguchi, H., Fukinbara, M., Tanaka, N., Shikanai, S., Sarukura, N., Tzu-Fang., H.S.U., Yueching, W. \& Yamamoto, S. 2012. Sugar intakes from snacks and beverages in Japanese children. Journal of Nutritional Science and Vitaminology 58(2): 113-117.

Tanzil, S. \& Jamali, T. 2016. Obesity, an emerging epidemic in Pakistan - A review of evidence. Journal of Ayub Medical College Abbottabad: JAMC 28(3): 597-600.

The Economist Intelligence Unit. 2017. Tackling Obesity in ASEAN. http://www.eiu.com/Handlers/WhitepaperHandler. ash $\mathrm{x}$.fi=Tackling-obesity-in-ASEAN.pdf\& mode=wp\&cam paignid=ObesityInASEAN. pp. 1-4.

The World Bank Group. 2018. GNI Per Capita, PPP.

Tremmel, M., Gerdtham, U.G., Nilsson, P.M. \& Saha, S. 2017. Economic burden of obesity: A systematic literature review. International Journal of Environmental Research and Public Health 14(4): E435.

Turner, B. 2014. Asian Development Bank Institute. In The Statesman's Yearbook. The Statesman's Yearbook, edited by Turner B. London: Palgrave Macmillan.

Wang, H., Jeong, H., Kim, N., Kang, Y., Hwang, K., Lee, H. \& Hong, J. 2018. Association between beverage intake and obesity in children. The Korea National Health and Nutrition Examination Survey (KNHANES) 2013-2015. 12(4): 307-314

WHO. 2015. Healthy Diet. Fact Sheet N394. p. 6. https://doi.org $/ 10.1080 / 00380768.2011 .576397$

WHO. 2016. Obesity and overweight: Fact sheet.

WHO. 2018. Global Nutrition Policy Review 2016 -2017: Country progress in creating enabling policy environments for promoting healthy diets and nutrition (DRAFT). (February). https://doi.org/10.1002/fld.3881.

World Bank Data Team. 2019. New country classifications by income level: 2018-2019.

World Health Organization. 2016a. Prevalence of Obesity among Adults, BMI $\geq 30$, Age-Standardized. Estimates by Country. Global Health Observatory. http://gamapserver. who.int/gho/interactive_charts/ncd/risk_factors/obesity/ atlas.html.

World Health Organization. 2016b. Prevalence of Overweight among Adults, BMI $\geq 25$, Age-Standardized. Estimates by Country. Global Health Observatory. http://gamapserver. who.int/gho/interactive_charts/ncd/risk_factors/ overweight/atlas.html.

World Health Organization (WHO). 2016. Fiscal Policies for Diet and Prevention of Noncommunicable Diseases: Technical Meeting Report. World Health Organization, (May). pp. 1-36.

Yun, S., Kim, H.J. \& Oh, K. 2017. Trends in energy intake among Korean adults, 1998-2015: Results from the Korea National Health and Nutrition Examination Survey. Nutrition Research and Practice 11(2): 147-154.

Wu-Dong-Yan Goh

School of Biosciences

Faculty of Health and Medical Sciences

Taylor's University

47500 Subang Jaya, Selangor Darul Ehsan

Malaysia

Li-Choo Chong*, Yau-Hoong Kuan \& Mohamed Noor Mohamed Ismail

Department of Culinology ${ }^{\circledR}$

School of Culinary Arts and Food Studies

Taylor's University, 47500 Subang Jaya

Selangor Darul Ehsan

Malaysia

*Corresponding author; email: lichoo.chong@taylors.edu.my

Received: 23 August 2019

Accepted: 29 October 2019 
